\title{
Problems faced by the rural women beneficiaries in participating shouhardo II program
}

\author{
TD Nath ${ }^{1 *}$, MJ Hoque ${ }^{2}$, MG Farouque ${ }^{3}$
}

Department of Agricultural Extension Education, Bangladesh Agricultural University Mymensingh-2202, Bangladesh

\begin{abstract}
The main focus of the study was to identify and describe the problems faced by the rural women beneficiaries in participating in SHOUHARDO II program. The study was conducted in Doribhabkhali village of Bhabkhali Union Parisad of Mymensingh Sadar Upazila under Mymensingh district. Data were collected from sixty rural women beneficiaries from 381 beneficiaries using random sampling method in April, 2015. The highest proportion of the rural women beneficiaries (41.7 percent) faced medium problems in participating program, while 33.3 percent of them had low problems. Among nine selected problems "religious obstacle" got the highest score (TOSS-156) and hence was considered as $1^{\text {st }}$ ranked problem and "incompatibility with the participants" got the lowest score (TOSS-29) and hence was considered as $9^{\text {th }}$ ranked problem. The selected characteristics of the respondents, such as household size showed positive relationship while extension media contact and social mobility showed negative with problem confrontation in participating SHOUHARDO II program. On the basis of probable solutions (correct interpretation of religious issues, increasing duration of training program etc.) made by rural women beneficiaries, necessary steps should be taken to reduce the faced problems.
\end{abstract}

Key words: Problem, rural women, participation, shouhardo ii program

Progressive Agriculturists. All rights reserve ～*Corresponding Author: tomadebnath763@yahoo.com

\section{Introduction}

Bangladesh is an agricultural based small deltaic country with a high population growth rate 1.3 per annum. Among total population (approximately 147.57 million) women constitute about half (49.4 percent) of the total population (BBS, 2012). Women make essential contributions to the agriculture from the ancient time. They at first started the agricultural activities in ancient. Women in rural Bangladesh are in general responsible for most of the agricultural work in the homestead. So, women play significant and crucial role in agricultural development and its allied fields (Samanta, 2005).

Today around one crore sixty-eight lakh women are engaged in agriculture, industry and different sectors (Shah, 2015). Women in Bangladesh also have diversified roles in fisheries, with substantial participation in small-scale fisheries. Women are also predominantly involved in net-making and freshwater fish farming.

In Bangladesh social, economic and political structures generate norms and practices of women' subordination to men, the consequences of which are women's relative lack of choice and agency in decision and processes that shape their welfare both in an absolute and in a relative sense and reduce subordination through the expansion of choice and by achieving the capacity to exercise agency in choosing (Mahmud, 2002). Most women live remained centered on their traditional roles and they had limited access to markets, productive services, education, health care, and local government. Different specialist works with this issue and showed 
that this occurred due to 66 percent girls got married before becoming 18 years (Ahmed, 2015).

To improve women situation different GOs and NGOs works for their welfare. They launch different projects and programs for women. SHOUHARDO II (Strengthening Household Ability to Respond to Development Opportunities II) is a program implemented by CARE Bangladesh funded by USAID and Bangladesh Government. The aim of SHOUHARDO II Program was to reduce food insecurity among Bangladesh's poor and extreme poor households by addressing underlying causes, including women's empowerment and livelihoods. That's why this program provide training for rural women on different issues such as agriculture, fisheries, homestead gardening, rights and laws of women etc. to make them self-reliant. But due to rural women's present situation in our country they faced different problems in participating this program. If their problems can be reduced, then they will be able to harvest more benefit from this training program. Through considering the facts, the researcher undertook the research and formulated to identify and describe the problems, select characteristics and explore the relationships between the selected characteristics of the rural women beneficiaries and their problems in participating shouhardo II program.

\section{Materials and Methods}

\section{Study area population and sampling}

The study was conducted in Doribhabkhali village of Bhabkhali Union Parisad of Mymensingh Sadar Upazila under Mymensingh district. The study area was selected purposively for survey with the help of concerned program officer of CARE Bangladesh in Mymensingh. The upazila where shouhardo II program are getting popularity among rural women was a major criterion for selecting the study location. Moreover, the researcher was highly acquainted with the present socio-economic condition of the study area and was able to create good relationships with the respondents in the study area in order to collect reliable data. Rural women who involve in the shouhardo II program of the study village were the target population of this study. The total number of rural women beneficiaries of the village was 381 , out of which 16 percent (60) were selected as sample size. The survey was conducted with the help of structured interview schedule from 01 April to 30 April, 2015 using random sampling method. Before collecting final data, two Focus Group Discussions (FGDs) was conducted to construct interview schedule.

\section{Selection and measurement of explanatory and focus variables}

The explanatory variables of the study were 10 selected characteristics of rural women beneficiaries. These were age, formal education, household size, farm size, total income, individual contribution in annual family income, training experience, credit facility, extension media contact and social mobility. Based on raw data through developing scale most of the explanatory variables were measured (Table 1).

Problems faced by the rural women beneficiaries in participating in shouhardo II program was the focus variable of the study. To measure the extent of problem faced by the rural women beneficiaries were asked to give their response against 9 selected problems using 4-point rating scale. The weights assigned for each response were: 3 for high problem, 2 for medium problem, 1 for low problem and 0 for not at all.

The problem score could vary from 0 to 27 , where 0 indicating 'no problem' and 27 indicating 'highest problem'.

In order to determine the extent of problem faced of a specific statement total observed score of that statement (TOSS) was determined by using the following formula:

Total observed score of a statement $=\left(\mathrm{Pf}_{\mathrm{h} \times} 3\right)+\left(\mathrm{Pf}_{\mathrm{m} \times}\right.$ $2)+\left(\mathrm{Pf}_{1 \times} 1\right)+\left(\mathrm{Pf}_{\mathrm{n} \times} 0\right)$

Where,

$\mathrm{Pf}_{\mathrm{h}}=$ Total number of rural women beneficiaries indicating high problem

$\mathrm{Pf}_{\mathrm{m}}=$ Total number of rural women beneficiaries indicating medium problem

$\mathrm{Pf}_{1}=$ Total number of rural women beneficiaries indicating low problem

$\mathrm{Pf}_{\mathrm{n}}=$ Total number of rural women beneficiaries indicating not at all problem 
Thus, total observed score of faced problem could be ranged from 0 to 180 while 0 indicating "no problem" and 180 indicating "highest problem" faced by the respondents.

\section{Probable solutions of the faced problems}

Suggestions were also identified through discussing with rural women beneficiaries. From the identified suggestions rank order was made based on the number of responses made by them.

Statistical measures such as mean, range, number, percentage standard deviation and rank order were used whenever necessary. The inferential statistics such as Pearson's product moment correlation coefficient (r) was conducted to show the relationship between selected characteristics of rural women beneficiaries and problems faced by them in participating shouhardo II program.

\section{Result and Discussion}

\section{Selected characteristics of the rural women beneficiaries}

Problems faced by the rural women beneficiaries in participating in shouhardo II program was affected by their selected characteristics. Selected ten characteristics of the rural women beneficiaries have been presented in Table 1 .

Table 1. Selected characteristics of the rural women beneficiaries

\begin{tabular}{|c|c|c|c|c|c|c|}
\hline \multirow{2}{*}{$\begin{array}{c}\text { Selected } \\
\text { characteristics }\end{array}$} & \multicolumn{2}{|c|}{ Score range } & \multirow{2}{*}{$\begin{array}{c}\text { Category of rural women } \\
\text { beneficiaries }\end{array}$} & \multirow[t]{2}{*}{ Percent } & \multirow[t]{2}{*}{ Mean } & \multirow[t]{2}{*}{ SD } \\
\hline & Possible & Observed & & & & \\
\hline \multirow{3}{*}{ Age (Years) } & \multirow{3}{*}{ Unknown } & \multirow{3}{*}{$22-68$} & Young (up to 35) & 48.3 & \multirow{3}{*}{37.48} & \multirow{3}{*}{10.66} \\
\hline & & & Middle age (36-55) & 45 & & \\
\hline & & & Old $(>55)$ & 6.7 & & \\
\hline \multirow{4}{*}{$\begin{array}{l}\text { Formal education } \\
\text { (Total year of } \\
\text { schooling) }\end{array}$} & \multirow{4}{*}{ Unknown } & \multirow{4}{*}{$0-10$} & No schooling (0) & 3.3 & \multirow{4}{*}{3.35} & \multirow{4}{*}{3.15} \\
\hline & & & Can sign only (0.5) & 45 & & \\
\hline & & & Primary $(1-5)$ & 28.3 & & \\
\hline & & & Secondary (6-10) & 23.3 & & \\
\hline \multirow{3}{*}{$\begin{array}{l}\text { Household } \\
\text { Size (No. of family } \\
\text { members) }\end{array}$} & \multirow{3}{*}{ Unknown } & \multirow{3}{*}{$1-11$} & Small (1-4) & 40 & \multirow{3}{*}{5.28} & \multirow{3}{*}{2.02} \\
\hline & & & Medium (5-8) & 45 & & \\
\hline & & & Large $(>8)$ & 15 & & \\
\hline \multirow{5}{*}{$\begin{array}{l}\text { Farm size } \\
\text { (Hectare) }\end{array}$} & \multirow{5}{*}{ Unknown } & \multirow{5}{*}{$0.01-0.36$} & Landless $(<0.02 \mathrm{ha})$ & 6.7 & \multirow{5}{*}{0.18} & \multirow{5}{*}{0.11} \\
\hline & & & Marginal (.02-0.2 ha) & 45 & & \\
\hline & & & Small (0.21-1 ha) & 48.3 & & \\
\hline & & & Medium (1.01-3 ha) & 0 & & \\
\hline & & & Large $(>3.0 \mathrm{ha})$ & 0 & & \\
\hline \multirow{3}{*}{$\begin{array}{l}\text { Total income }(000 \text { ' } \\
\text { Taka) }\end{array}$} & & & Low $(<50)$ & 71.7 & & \\
\hline & Unknown & $3-154$ & Medium (51-100) & 20 & 41.04 & 37.35 \\
\hline & & & High $(>100)$ & 8.3 & & \\
\hline Individual & & & Low $(<50)$ & 100 & & \\
\hline contribution to the & Unknown & & Medium (51-100) & 0 & 4.66 & 7.83 \\
\hline $\begin{array}{l}\text { annual family } \\
\text { income (000' Taka) }\end{array}$ & & $0-48$ & High $(>100)$ & 0 & & \\
\hline Selected & Sco & range & Category of rural & Percent & Mean & SD \\
\hline characteristics & Possible & Possible & women beneficiaries & & & \\
\hline Training experience & & & Short $(0-4)$ & 81.7 & & \\
\hline (No. of days) & Unknown & $0-14$ & Medium (5-9) & 15 & 3.36 & 2.36 \\
\hline & & & Long $(>9)$ & 3.3 & & \\
\hline & & & Low $(0-20)$ & 66.7 & & \\
\hline Credit facility $\left(000^{\prime}\right.$ & Unknown & $0-70$ & Medium (21-45) & 18.3 & 20.83 & 18.53 \\
\hline Taka) & & & High $(>45)$ & 15 & & \\
\hline & & & Low $(0-8)$ & 3.3 & & \\
\hline Extension media & $0-24$ & $8-21$ & Medium (9-16) & 85 & 13.05 & 3.24 \\
\hline contact (Scores) & & & High $(>16)$ & 11.7 & & \\
\hline Social mobility & $0-21$ & $3-21$ & Low $(0-6)$ & 15 & 12.15 & 4.42 \\
\hline (Scores) & & & Medium (7-12) & 31.7 & & \\
\hline & & & High $(12>)$ & 53.3 & & \\
\hline
\end{tabular}

Source: Field survey, 2015 
Data in Table 1 indicted that majority ( 48.3 percent) of the rural women beneficiaries of the study area were young aged having average formal education 3.35. Majority (48.3 percent) of the rural women beneficiaries having small farm size ( 0.21 to 1 ha) and had low total household income with an average value Tk. 41.04 thousand. Their individual contribution in annual family income is an average Tk. 4.66 thousand. Most of the training receiver women receive short duration training with a mean value of 3.36 days. They took loan from different NGOs with an average Tk. 20.83 thousand. They possess medium extension media contact status with an average score 13.05 and average social mobility score 12.15 .

\section{Rural women beneficiaries' problems in Participating shouhardo II Program}

Rural women beneficiaries' problem facing scores for 9 selected problems range from 6 to 15 with a mean of 12.48 and standard deviation (SD) 7.44. According to their overall problems faced score rural women beneficiaries were classified into three categories as shown in Table 2.

Table 2 Distribution of rural women beneficiaries according to their overall problems faced in participating shouhardo II program $(\mathrm{n}=60)$

\begin{tabular}{|c|c|c|c|c|c|c|}
\hline $\begin{array}{c}\text { Possible } \\
\text { score range }\end{array}$ & $\begin{array}{c}\text { Observed } \\
\text { score range }\end{array}$ & Categories of women & No. & Percent & Mean & SD \\
\hline \multirow{3}{*}{$0-27$} & \multirow{3}{*}{$6-15$} & Low problems $(<9)$ & 20 & 33.3 & \multirow{3}{*}{12.48} & \multirow{3}{*}{7.44} \\
\hline & & Medium problems $(10-18)$ & 25 & 41.7 & & \\
\hline & & High problems $(18>)$ & 15 & 25 & & \\
\hline
\end{tabular}

Source: Field survey, 2015

Data in Table 2 indicated that the highest proportion (41.7 percent) of the rural women beneficiaries were faced medium problem, while 33.3 percent of them were faced low problem. Total observed score of a specific statement of the problems faced by rural women beneficiaries was calculated and rank order was made according to total observed score of a specific statement as shown in Table 3.

Table 3. Rank order of the problems faced by rural women beneficiaries in participating shouhardo II program $(n=60)$

\begin{tabular}{|c|c|c|c|c|c|c|}
\hline \multirow[t]{2}{*}{ Problems } & \multicolumn{4}{|c|}{ Extent of problems } & \multirow[b]{2}{*}{ TOSS } & \multirow{2}{*}{$\begin{array}{l}\text { Rank } \\
\text { Order }\end{array}$} \\
\hline & High (3) & Medium (2) & Low (1) & Not at all (0) & & \\
\hline Religious obstacle & 39 & 18 & 3 & 0 & 156 & 1 \\
\hline Obstacle from the society & 32 & 14 & 14 & 0 & 138 & 2 \\
\hline Obstacle from the other family members & 17 & 13 & 6 & 24 & 83 & 3 \\
\hline Lack of proper transport facility & 0 & 9 & 37 & 14 & 55 & 4 \\
\hline Obstacle from the husband & 7 & 8 & 15 & 30 & 52 & 5 \\
\hline Lack of knowledge about the program & 0 & 9 & 21 & 30 & 39 & 6 \\
\hline Lack of attitude towards the program & 2 & 6 & 14 & 38 & 32 & 7 \\
\hline $\begin{array}{l}\text { Difficult to understand the subject matter } \\
\text { of the training }\end{array}$ & 4 & 4 & 11 & 41 & 31 & 8 \\
\hline Incompatibility with the participants & 7 & 3 & 2 & 48 & 29 & 9 \\
\hline
\end{tabular}

*TOSS $=$ Total Observed Score of a Statement, Source: Field survey, 2015

Data in Table 3 indicated that "religious obstacle" got the highest score (156) and hence was considered as $1^{\text {st }}$ ranked problem followed by obstacle from the society, obstacle from the other family members, lack of proper transport facility, obstacle from the husband, lack of knowledge about the program, lack of attitude towards the program, difficult to understand the subject matter of the training and incompatibility with the participants according to the score. "Incompatibility with the participants" got the 
lowest score (29) and hence was considered as $9^{\text {th }}$ ranked problem.

The aged persons of our society showed different religious causes such as women should remain always in veil; they should not go outside etc. Due to lack of knowledge and awareness, they created obstacle for women beneficiaries. Beside this, family members and husband suppressed women decision due to lack of proper knowledge and attitudes towards program. They thought that the program is funded by peoples from foreign country belongs other religion. So, women should not take part in that program.

Infrastructure facilities such as road in the village area were not so good in condition and the program also did not provide any transportation facilities for women beneficiaries. Most of the women's level of education is not high, so it made difficulties for them to understand the training subject matter. Incompatibility with the participants due to different social status, knowledge and socio-economic condition of the women is a common phenomenon in the study area. All of these problems hinder women participation in this program. Among all of these problems religious obstacle is very core problem and difficult to overcome.

\section{Relationship between the selected characteristics of the rural women beneficiaries and faced problems}

Pearson's product moment correlation was conducted to explore the relationship between problem faced by rural women beneficiaries and their selected characteristics have been shown in Table 4 .

Table 4. Correlation between explanatory and focus variables $(n=60)$

\begin{tabular}{|c|c|c|c|c|}
\hline \multirow[t]{2}{*}{ Focus variable } & \multirow[t]{2}{*}{$\begin{array}{l}\text { Selected personal socioeconomic } \\
\text { characteristics }\end{array}$} & \multirow[t]{2}{*}{$\begin{array}{l}\text { Correlation co-efficient } \\
\text { (r) with } 58 \mathrm{df}\end{array}$} & \multicolumn{2}{|c|}{$\begin{array}{l}\text { Tabulated values } \\
\text { of } \mathrm{r} \text { with } 58 \mathrm{df}\end{array}$} \\
\hline & & & 0.05 & 0.01 \\
\hline \multirow{10}{*}{$\begin{array}{l}\text { Problems faced } \\
\text { by the rural } \\
\text { women } \\
\text { beneficiaries in } \\
\text { participating } \\
\text { SHOUHARDO } \\
\text { II program }\end{array}$} & Age & -.210 & \multirow{10}{*}{0.25} & \multirow{10}{*}{0.324} \\
\hline & Formal education & .204 & & \\
\hline & Household size & $.264^{*}$ & & \\
\hline & Farm size & .094 & & \\
\hline & Total income & -.034 & & \\
\hline & $\begin{array}{l}\text { Individual contribution to the } \\
\text { annual family income }\end{array}$ & -.208 & & \\
\hline & Training experience & .009 & & \\
\hline & Credit facility & -.140 & & \\
\hline & Extension media contact & $-.517^{\text {** }}$ & & \\
\hline & Social mobility & $-.291^{*}$ & & \\
\hline
\end{tabular}

** Correlation is significant at the 0.01 level (2-tailed), * Correlation is significant at the 0.05 level (2-tailed).

The findings indicated that household size $\left(.264^{*}\right)$ had significant positive relationship and extension media contact $\left(-.517^{* *}\right)$ and social mobility $\left(-.291^{*}\right)$ had significant negative relationship with problem faced by the rural women beneficiaries in participating shouhardo II program.

Household size had significant positive relationship with women beneficiaries faced problems. In small household size, the family is headed by father and mother. They take all of the decisions for the welfare of the family. Women get priority and consider their opinion in all cases of family life. But in large household size, the family does not head by only husband and wife. The decisions of all levels of family members are considered. Hence, women problems also increased with the increase of the household size.

Extension media contact and social mobility had significant negative relationship with women beneficiaries faced problems. So, it can be concluded that women having higher extension media contact and social mobility faced low problems in 
participating the program. Women having more extension media contact and social mobility have more knowledge on different issues such as their rights, laws, their ability, they can take their own decision. Roy (2012) and Chowdhury (2014) found similar results in their respective research. They found extension media contact had significant negative relationship with problems.

Probable solutions mentioned by the women beneficiaries

The rural women beneficiaries were asked to mention some probable solutions for above mentioned problems as shown in Table 5.

Table 5. Rank order of probable solutions of the problems faced by the rural women beneficiaries

\begin{tabular}{|l|c|c|}
\hline $\begin{array}{l}\text { Solutions mentioned by the } \\
\text { women beneficiaries }\end{array}$ & $\begin{array}{c}\text { No. of } \\
\text { citation }\end{array}$ & $\begin{array}{c}\text { Rank } \\
\text { order }\end{array}$ \\
\hline $\begin{array}{l}\text { Correct interpretation of } \\
\text { religious issues }\end{array}$ & 60 & 1 \\
\hline $\begin{array}{l}\text { Increasing duration of training } \\
\text { program }\end{array}$ & 46 & 2 \\
\hline Increasing number of training & 41 & 3 \\
\hline $\begin{array}{l}\text { Increasing amount of input } \\
\text { facility }\end{array}$ & 39 & 4 \\
\hline Providing transport facility & 32 & 5 \\
\hline $\begin{array}{l}\text { Increasing amount of } \\
\text { incentives }\end{array}$ & 28 & 6 \\
\hline $\begin{array}{l}\text { Getting credit at low interest } \\
\text { rate }\end{array}$ & 17 & 7 \\
\hline
\end{tabular}

Source: Field survey, 2015

Data presented in Table 5 indicated that "correct interpretation of religious issues" is very essential followed by increasing duration of training program, increasing number of training, increasing amount of input facility, providing transport facility, increasing amount of incentives and getting credit at low interest rate according to no. of citation by the rural women beneficiaries.

"Correct interpretation of religious issues" was mentioned as first solution by all of the rural women beneficiaries. So that women can move outside their home, take part in income generating activities. Concerned authority of shouhardo II program can provide more number of training programs, available transport facility, incentives and distribute credit at low interest rate. If the women get input facilities, some incentives and credit with low interest rate then husband and other family members will support her to participate in the program, then women would be able to utilize all these facilities for her family as a helping hand. All of these solutions can helps to reduce all the problems faced by the rural women beneficiaries.

\section{Conclusions}

The findings of the study depict that majority (41.7 percent) rural women beneficiaries faced medium problems in participating shouhardo II program. The major problems faced by beneficiaries during participating shouhardo II program were religious obstacle, obstacle from society, obstacle from other family members and so on. These findings lead to conclude that, addressing these problems can help to increase their participation in different training programs and will be able to harvest more benefit from this. In the view of the urgent need for minimizing the problems of the women beneficiaries, necessary steps should be taken on a priority basis from the solutions made by them to remove problems causing hindrance women movement towards development.

\section{References}

Ahmed M (2015). Women are Still Laggards in Higher Education and Job. The Daily Prothom Alo, P. 1.

BBS (2012). Bangladesh Bureau of Statistics, Ministry of Planning, Government of People's Republic of Bangladesh, Dhaka.

Chowdhury RI (2014). Problems Faced by the Farmers in Organic Shrimp Farming. (Unpublished MS Thesis), Department of Agricultural Extension Education. Bangladesh Agricultural University, Mymensingh, Bangladesh.

Mahmud S (2002). Actually How Empowering is Micro Credit? Retrieved fromhttp://www. Micro creditsummito.org/paper/+5cheston_kuhn.da.

(Search date: 12 March, 2015).

Roy D (2013). Effectiveness of Farmer Field School for Soil and Crop Management. (Unpublished MS Thesis), Department of Agricultural 
Extension Education. Bangladesh Agricultural University, Mymensingh, Bangladesh.

Samanta RK (2005). Rural Development through Empowerment of Rural Women. pp: 63-74 in: R. K. Samanta (Ed.) Empowering Rural Women
Issues, Opportunities and Approaches. Delhi: The women Press.

Shah J (2015). March 8). Women Contribution is Increasing in Economy. The Daily Prothom Alo, P. 1 . 